\title{
Investigating the effects of building information modeling capabilities on knowledge manage- ment areas in the construction industry
}

\author{
Ali Rezahoseini ${ }^{a}$, Siamak Noori ${ }^{\mathrm{a}}$, Seyed Farid Ghannadpour ${ }^{\mathrm{a}^{*}}$ and Mostafa Bodaghi ${ }^{\mathrm{b}}$
}

${ }^{a}$ School of Industrial Engineering, Iran University of Science \& Technology, Tehran, Iran

${ }^{b}$ School of Architecture, College of Art and Architecture, University of Tehran, Tehran, Iran

\section{CH R O N I C L E}

Article history:

Received: June 102018

Received in revised format: July 1

2018

Accepted: August 62018

Available online:

August 72018

\section{Keywords:}

Project Management Knowledge (PMBOK)

Building Information Modeling (BIM)

Project Integrated Management

Construction Industry

\section{A B S T R A C T}

In order to manage a project seamlessly, there is a need to establish effective communication between different departments and identify the risks in the project, determine the affected or influencing stakeholders, provide timely resources and logistics, and manage the available resources to make a framework for project implementation. In order to successfully complete the project it is also necessary to focus on approved costs, project completion time and quality within the specified range. Project management is the coordination among different parts of the project to achieve the main goals of the project and the stakeholders' expectations. To achieve this, there are several standards and one of the most recognized standards is the Project Management Knowledge Facility (PMBOK), which has come with the assistance of Project Managers for professional, targeted and comprehensive management. PMBOK is not just a guideline and a methodology for project management. Building Information Modeling (BIM), a project management methodology has been adopted in recent years to design a project integrated as a 3-D information model, which adds all project information in the various phases of the project to a 3-D information model. The purpose of this research is to gather some date from experts using some questionnaires in the area of project management to build an information modeling. The study determines that each of the basic BIM capabilities had positive effects on different domains of PMBOK knowledge. Moreover, using SAW analysis, the study suggests that BIM had the greatest impact on project integration management, and finally, the BIM general process model is introduced to implement each of the areas of knowledge.

(C) 2019 by the authors; licensee Growing Science, Canada.

\section{Introduction}

The increasing acceptance of Project Management as a career, expresses that using the proper knowledge, processes, abilities, tools, and techniques, can have a considerable impact on projects success, and reduce the problems (that may rise) in a project. PMBOK project management standard and its body/fields of knowledge are widely accepted by the public as a proper method; this standard is more of guide than a special methodology (Larson \& Gray, 2015). That is to say project management standards only specify the required framework to achieve the project goals, but they do not show/lead the way to them; thus, we need tools and techniques that lead us to the desired goals in a project. The construction industry has been continuously criticized world-wide for its unwillingness to employ and implement new technologies, slow pace of increasing productivity, and also for its limitations and inability in project management (Alshawi \& Ingirige, 2003). Old-fashioned contracts, inexact building

\footnotetext{
* Corresponding author

E-mail address: ghannadpour@iust.ac.ir (S. F. Ghannadpour) 
plans, disintegrate among project team members throughout the project, long and flawed processes of construction projects design and execution, unnecessary time consuming repetition (reworking) of tasks resulting from engineers' analytic mistakes, unwillingness of the design team to implement changes, difficult and vague value engineering, cost estimations based on imprecise and outdated price lists, and the lack of a comprehensive and understandable image of the project for the employer, are just some of the problems that construction companies are involved with on a daily basis. A main reason for the emergence of such problems in construction projects, is the lack of functioning data collection systems customized to meet the needs of construction industry. The use of a system that in addition to data collection and classification can be easily employed by the main agents involved in the project may enhance communications, and thus make a considerable contribution to the project management (Autodesk, 2011). Studies show that Building Information Modeling (BIM) contains such capacities, and its widespread employment in construction industry across the country can eliminate many problems; and play a significant role in increasing productivity and project management in the industry (Broquetas, 2010). BIM takes place before the execution of a project, and at each stage the required information are added to it by various teams and individuals. Not only is this information used during the design and construction [stages]; but, they are also useable to the users after the project delivery and during the utilization phase. Formation of a useful data base, cooperation and harmony among various project agents involved in the making of the model, organization of all production plans, decrease in design/planning errors, diagnosis of mistakes in design/plan, possibility of adding cost and timing information to the model, and assisting in facility management during the utilization phase, are just some of the capacities of such models (Azhar, 2011). The differentiating aspect between BIM and other methods of designing and presenting construction projects lies in their framework; information is the solution this method (BIM) suggests, (in other words) adding various data to the building model (including the timing, equipment, material, cost, and etc. data). Such data can be analyzed, and made available to the people who benefit from them when required (Young, et al., 2009; Golabchi et al., 2013).

In this research, we first review the knowledge management areas of the project and how they relate to each other, and then building information modeling (BIM) and its capabilities throughout the life cycle of the project will be be introduced. Continuing through questionnaires from project management and BIM experts, the impact of each BIM capabilities on knowledge areas will be discussed. Then, using SAW analysis, we examine and rank the impact of each project management knowledge domain on BIM capabilities, and ultimately, the BIM process model for implementing knowledge management areas will be presented, we determine that we can use building information modeling as a suitable methodology for implementation of knowledge management areas of projects in projects.

\section{Theoretical Foundations and Review of Literature}

\subsection{Project Management Body of Knowledge and Their Correlation}

The acceptance of project management as a career, shows that using knowledge, processes, skills, tools, and techniques, can play an important role projects success. The PMBOK guide, represents a wide variety of project management knowledge subsets, and is generally recognized as a suitable approach. The necessary knowledge for project management, and project execution processes have been respectively categorized in 10 management-subgroups and 5 process-subgroups. In the field of Project Management knowledge, understanding the factors influencing the project and their management, can integrate the project execution processes to achieve the desired goal/purpose (Larson \& Gray, 2015). Table 1 provides the definitions of Project Management fields of knowledge through the perspective of PMBOK. 
Table 1

Project Management knowledge

Project Management knowledge

\begin{tabular}{|c|c|}
\hline $\begin{array}{l}\text { Project Management } \\
\text { fields of knowledge }\end{array}$ & Description \\
\hline $\begin{array}{l}\text { Integrated } \\
\text { Management }\end{array}$ & $\begin{array}{l}\text { Processes and activities needed to identify, define, combine, unify and harmonize process and activities in different pro- } \\
\text { cedure-groups of Project Management (Larson \& Gray, 2015). }\end{array}$ \\
\hline Scope Management & $\begin{array}{l}\text { The required process to ensure that the project contains all the required tasks to achieve success. Project Scope Manage- } \\
\text { ment encompasses defining and controlling all the things that the project includes (or does not include) (Larson \& Gray, } \\
2015 \text { ). }\end{array}$ \\
\hline Time Management & The needed processes for on-time delivery of the project (Larson \& Gray, 2015). \\
\hline Costs Management & $\begin{array}{l}\text { The processes of cost-estimation, budgeting, and cost management to keep the project within the confirmed budget (Larson } \\
\text { \& Gray, 2015). }\end{array}$ \\
\hline Quality Management & $\begin{array}{l}\text { The processes and activities of executive organizations, which determine the policies, goals, and responsibilities in order } \\
\text { to meet the required promises (Larson \& Gray, 2015). }\end{array}$ \\
\hline Risk Management & $\begin{array}{l}\text { The process of directing and planning risk management, involves identifying, analyzing, reaction planning, supervising, } \\
\text { and controlling the project risks (Larson \& Gray, 2015). }\end{array}$ \\
\hline $\begin{array}{l}\text { Resource Manage- } \\
\text { ment }\end{array}$ & $\begin{array}{l}\text { Project resource management encompasses stages such as identifying, achieving, and managing the necessary resources } \\
\text { for the successful delivery of the project. This process ensures that sufficient resources are available to the project manager } \\
\text { and the project team where and when resources are needed (Larson \& Gray, 2015). }\end{array}$ \\
\hline $\begin{array}{l}\text { Procurement } \\
\text { Management }\end{array}$ & $\begin{array}{l}\text { The needed procedures for purchasing or attracting products, services, or achieving results, outside the project team (Lar- } \\
\text { son \& Gray, 2015). }\end{array}$ \\
\hline $\begin{array}{l}\text { Communication } \\
\text { Management }\end{array}$ & $\begin{array}{l}\text { The on time and appropriate process of collecting, distributing, saving, and retrieving project data (Larson \& Gray, 2015; } \\
\text { Wong \& Fan, 2013). }\end{array}$ \\
\hline $\begin{array}{l}\text { Stakeholders } \\
\text { Management }\end{array}$ & $\begin{array}{l}\text { The needed processes to identify individuals, groups, and organizations influencing or influenced by the project in order } \\
\text { to have an analysis of stakeholder and how they affect the project; so that an appropriate management strategy can be } \\
\text { employed to attract their participation in project decisions and execution (Larson \& Gray, 2015). }\end{array}$ \\
\hline
\end{tabular}

A project is considered successful when, it is completed within the determined time and budget, has a quality that fits the expected scope, and the employer is satisfied about the execution process. Thus, time management, cost management, quality management, and scope management can be considered as the primary knowledge of project management; and knowledge fields of resources, communications, risks, procurements, and stakeholders are secondary and contributing to the primary fields. Finally, all such knowledge need to be coordinate and integrated to guarantee project success. Project management standard and its fields of knowledge are rather used as a guide instead of being an independent methodology. In other words, this standard indicates the necessary frameworks to achieve success in a project, but does not lead to it. Therefore, one can employ different methodologies, tools, and techniques (such as Agile or Waterfall methodologies) to create a project management framework that leads to project goals (Larson \& Gray, 2015). Likewise, the present study introduces BIM as a constructive tool for integrated project management and the influence of such management on project management fields of knowledge.

\subsection{Building Information Modeling (BIM)}

During the early 1960s, the construction industry faced a gradual reduction in productivity of the human resources. Meanwhile, other industries were enjoying an enhanced productivity of the human resources (Rooke, et al., 2004). Island-like nature of the construction industry due to its approach to contracts, its use of 2D drawing methods (CAD Software), and the size and magnitude of the construction companies can be regarded as the main reasons for a low productivity indicator (Teicholz, 2004). Here, the inefficiency of $2 \mathrm{D}$ design methods in accomplishing an effective communication with the stakeholders can be pointed to as a significant factor. In a situation where each of the factors involved in the 2D plans corresponded to its related discipline, the plans that lacked the capacity to integrate and adapt to other plans, led to information conflicts and therefore a reduction in the workforce productivity (Teicholz, 2004). On the other hand, 2D designs lacked the capacity to integrate with and encompass the costs and planning information. Moreover, the downward flow of construction workforce payments had led to lack of pressure for an increase in worker's productivity. Thus, any attempts to come up with new methods was not economically justified (Teicholz, 2004). In 1997 a new revolution introduced a 3D design tool that used a shared data source. Such a shared data source made the changes in designs-at any point of the designs-possible and automatically applied the changes to other design documents. The database could also be shared between large numbers of users. Architecture, structure, and facility 
models could be made as linked and merged together (Migilinskas, et al., 2013). According to Eastman et al. (2011), BIM is more than a software, it is a human activity that transforms design, construction, and construction management processes. General Services Administration (GSA) defines BIM as: "Building Information Modeling is the development and use of a multi-faceted computer software data model to not only document a building design but to simulate the construction and operation of a new capital facility or a recapitalized (modernized) facility. The resulting Building Information Model is a data-rich, object-based, intelligent and parametric digital representation of the facility, from which, views appropriate to various users' needs can be extracted and analyzed to generate feedback and improvement of the facility design" (Parvan, 2012). BIM has the capacity to bring together all the required information during the project lifecycle including, spatial relations, geographical position, quantity and specifications of building parts, cost estimation, list of materials, and the project schedule. The integrity of the information extracted from the design process, and its consequent coordination of information, make BIM stand out in comparison with the CAD-based design methods. In order to have a better understanding, CAD data can be compared to detached islands, while BIM data can be associated with connected and unified ones.

\subsection{Various Aspects of Building Information Modeling}

BIM is the digital evolution form the traditional 2D model to 3D and even to 4D (determining a time plan) and 5D (cost estimation) models; it uses a shared database throughout the construction life cycle. The characteristics of parametric modeling and the capacities of intersectional cooperation facilitate this evolution process. The aspects of BIM follow as such:

$\checkmark$ 3D Model: The mathematical presentation in any 3D level such as width, length, and height of an object. In other words, 3D BIM includes plan, spatial relations, geographical, and geometric information. For example, the width, length, and height of the building sections (Liu, 2010).

$\checkmark$ 4D Model: The addition of a fourth dimension-that is the time plan-to any 3D BIM model. The $4 \mathrm{D}$ establishes communication between $3 \mathrm{D}$ elements and the project delivery timeline, and thus provides the possibility of simulating the virtual process of project construction in a 4D environment to the users (Dang \& Tarar, 2012).

$\checkmark$ 5D Model: The addition of a fifth dimension means to add the data of cost estimation to the 3D model. Any 5D model, for instance, connects the costs data to the list of amounts and materials $(\mathrm{QTO})^{1}$ derived from the 3D model, thus adding to the preciseness and trueness of the project cost estimation (Liu, 2010).

The items considered in this data model are:

1-The simultaneous estimation of costs based on the designed mental model, before the execution phase.

2-The capacity to separate the costs of each section, and a more precise and complete estimation of the demanded items

3 -Value engineering based on the results

4- Overcoming issues before they occur

5 -Estimation of the major costs

6- Achieving a database for being used in similar cases

$\checkmark$ 6D Model: When the construction project is ready to be delivered, the 6D model is given to the owners for the purpose of managing the facilities. The model includes information such as the details and data of products, maintenance and utilization methods, photos, warranty data, communication links to online sources of production, contracts, construction information, etc. The model assists the managers of the building in its maintenance and utilization throughout the life time of the construct (Elbeltagi \& Dawood, 2011).

\footnotetext{
${ }^{1}$ Quantity take-offs
} 
7D Model: The sevenths dimension of BIM is related to maintenance and repair of the building facilities during the utilization time.

In Table 2, a set of BIM capabilities is expressed throughout the life cycle of the project.

Table 2

BIM Capacities and Functions

\begin{tabular}{|c|c|c|}
\hline \multicolumn{3}{|r|}{ BIM Capacities and Functions } \\
\hline 1 & Parametric members & $\begin{array}{l}\text { Parametric data are the data that differentiate one part from other similar parts. For instance, although all of the walls } \\
\text { are designed through a tool menu, they are also made of unique parameters, such as dimensions, materials, or a specific } \\
\text { supplying company, which differentiate them from other walls. In addition, the intelligence of the parts in modeling } \\
\text { is not limited to them, they are also assessable in relation to the rest of the parts (Eastman, et al., 2011). }\end{array}$ \\
\hline 2 & $\begin{array}{l}\text { 3D Model, Increased } \\
\text { Vision Precision, and } \\
\text { Reduction of Claims }\end{array}$ & $\begin{array}{l}\text { The complexity of work, length of the execution phase, and different interpretations of the project by the contract } \\
\text { parties are the bed form which claims rise. Contract parties having access to a 3D model of the project before the } \\
\text { execution, negates all the cases of various interpretations, work complexity, and extra time. That is to say, an appro- } \\
\text { priate project management reduces the rise of claims (Eastman, et al., 2011). }\end{array}$ \\
\hline 3 & $\begin{array}{l}\text { Integrated Change } \\
\text { Management }\end{array}$ & $\begin{array}{l}\text { The users can have access to any required } 2 \mathrm{D} \text { designs through BIM model (horizontal, vertical ...cuts). In case of } \\
\text { changes to any of the parts, the change applies to any other dependent part(s) as a result of (the parts) being parametric } \\
\text { (Winberg \& Dahlqvist, 2010). }\end{array}$ \\
\hline 4 & Fabrication & $\begin{array}{l}\text { Because of the availability of all required constituent parts and sections, BIM, makes pre-construction (out of the } \\
\text { construction site) possible (Winberg \& Dahlqvist, 2010). }\end{array}$ \\
\hline 5 & Documentation & $\begin{array}{l}\text { At the end of the project, the project manager can present a comprehensive model of building information to the client. } \\
\text { A model which includes information such as: links to approvals, maintenance and utilizing information, warranties, } \\
\text { guarantees, security and safety information (such as lighting information and firefighting system, alarm, and smoke } \\
\text { sensors); in addition the facilities management team, based on the information given to the client, can execute energy } \\
\text { analysis and optimization systems during the facilities utilizing time period (Hergunsel, 2011). }\end{array}$ \\
\hline 6 & $\begin{array}{l}\text { Construction Pro- } \\
\text { cess Simulation, and } \\
\text { Saving Time during } \\
\text { the Project Execu- } \\
\text { tion }\end{array}$ & $\begin{array}{l}\text { A 4D model can be gained by integration of graphic images with the time dimension. In 3D modeling, a graphic } \\
\text { model of } 3 \text { spatial dimensions is connected to the time dimension, so the order and sequences of different project } \\
\text { steps are shown in real-time. 4D modeling tool enables the project planner to plan activities with respect to time and } \\
\text { space dimensions. This makes, the coordination of execution methods with the [construction] site conditions, place- } \\
\text { ment of crane tower, burrowing details, and such activities, possible. The studies show that 4D models indicate the } \\
\text { design conflicts before the execution phase, and reduce the spatial-temporal conflicts and eliminate their ensuing } \\
\text { rework (Eastman, et al., 2011). }\end{array}$ \\
\hline 7 & $\begin{array}{l}\text { 5D Model, and Pre- } \\
\text { cise Quantity Sur- } \\
\text { veying and Cost Es- } \\
\text { timation }\end{array}$ & $\begin{array}{l}\text { A 5D model of building information requires integration of the } 3 \mathrm{D} \text { model with time and cost aspects of the project. } \\
\text { This makes the anticipation and tracing of the project costs during any of the various phases possible (Dang \& Tarar, } \\
2012 \text { ). In this system, the extraction of the work amounts and the required materials, also other dimension details, } \\
\text { from the 3D model, are very easy (Hergunsel, 2011). }\end{array}$ \\
\hline 8 & $\begin{array}{l}\text { Equipment Manage- } \\
\text { ment }\end{array}$ & $\begin{array}{l}\text { The equipment management groups can utilize BIM for renovation, spatial planning, and building maintenance (East- } \\
\text { man, et al., 2011). }\end{array}$ \\
\hline 9 & $\begin{array}{l}\text { Facility Manage- } \\
\text { ment }\end{array}$ & $\begin{array}{l}\text { One of the most important functions of BIM in the management of the facilities is the collection and record of the } \\
\text { needed data on the parts and equipment used in the building, to be referred to during the utilization period. The data } \\
\text { regarding performance inspection, warranty period, equipment and materials features, etc. can play a problem-solving } \\
\text { role in the maintenance process (Akula, 2013). }\end{array}$ \\
\hline 10 & $\begin{array}{l}\text { Sustainable Design } \\
\text { and Construction }\end{array}$ & $\begin{array}{l}\text { The smart data made through BIM, have the capacity to assess total building energy, simulate its (energy) perfor- } \\
\text { mance, selecting the best approach/orientation to it, internal lighting analysis, and the presentation of such assessments } \\
\text { (Krygiel \& Nies, 2008). }\end{array}$ \\
\hline 11 & Constructability & $\begin{array}{l}\text { An established capacity of BIM is the coordination of the various groups of design (Architecture, construction, and } \\
\text { facilities), and therefore maximal adaptation of design and construction processes. This has a meaningful effect on } \\
\text { reducing the costs and time of the project. }\end{array}$ \\
\hline 12 & Enhancing Safety & $\begin{array}{l}\text { BIM is known as a tool for improving the safety and health of the workforce. BIM can be used for, training the } \\
\text { workforce, safety-based design of the construction site, safety planning (analyzing workplace dangers,), identifying } \\
\text { and analyzing the risk management factors, determining the excavation equipment scope of motion, determining the } \\
\text { storage place of materials and pre-made parts, and determining the security and safety measures during the utilization } \\
\text { and maintenance phases. Through making a shared 3D model of the buildings for the groups involved in design and } \\
\text { construction, BIM reduces the risks during the construction (Khoshnava et al., 2010). }\end{array}$ \\
\hline 13 & Conflict Detection & $\begin{array}{l}\text { Since the virtual 3D model of the building is the source of all } 2 \mathrm{D} \text { and } 3 \mathrm{D} \text { plans, the design errors resulting from the } \\
2 \mathrm{D} \text { plans are eliminated. Conflicts and constructability problems are identified before happening in the site. Coordi- } \\
\text { nation between designers and contractors rises, and negligence is significantly reduced. This capacity accelerates the } \\
\text { construction process, reduces costs, minimizes the probability of legal conflicts, and brings about an easier construc- } \\
\text { tion process for the project team (Eastman, et al., 2011). }\end{array}$ \\
\hline 14 & $\begin{array}{l}\text { Cooperation be- } \\
\text { tween the Project } \\
\text { Team }\end{array}$ & $\begin{array}{l}\text { The design and construction of a building are group and team activities. Naturally working with various models is } \\
\text { more difficult and time-consuming, compared to working with an integrated 3D model. In such a 3D model, change } \\
\text { control can be managed better, while cooperation through drawings is also possible. This reduces the design time and } \\
\text { minimizes the mistakes and errors of the design process. It provides new insights regarding the design problems and } \\
\text { also provides opportunities for the constant improvement of the design (Eastman, et al., 2011). }\end{array}$ \\
\hline 15 & $\begin{array}{l}\text { Improving Commu- } \\
\text { nication, and Rein- } \\
\text { forcing Cooperation } \\
\text { and Coordination }\end{array}$ & $\begin{array}{l}\text { By using BIM, anyone can see their task in relation to others. On a data exchange level, the building model, because } \\
\text { of high readability, supports the automatic translation of BIM and accessibility of the design information for anyone- } \\
\text { throughout the design and construction processes (Eastman, et al., 2011). }\end{array}$ \\
\hline 16 & $\begin{array}{l}\text { Quick Response to } \\
\text { Changes in the De- } \\
\text { sign }\end{array}$ & $\begin{array}{l}\text { The changes in the proposed design can impact the construction model, and automatically apply the changes on the } \\
\text { other objects. The updates are done automatically and are based on rational parametric laws. Moreover, the changes } \\
\text { in design can be applied faster through BIM, that is because the corrections can be shared, analyzed, and applied } \\
\text { without the time consuming paper-based processes (Eastman, et al., 2011). }\end{array}$ \\
\hline
\end{tabular}


Fig. 1 illustrates the capabilities of building information modeling throughout the project cycle.

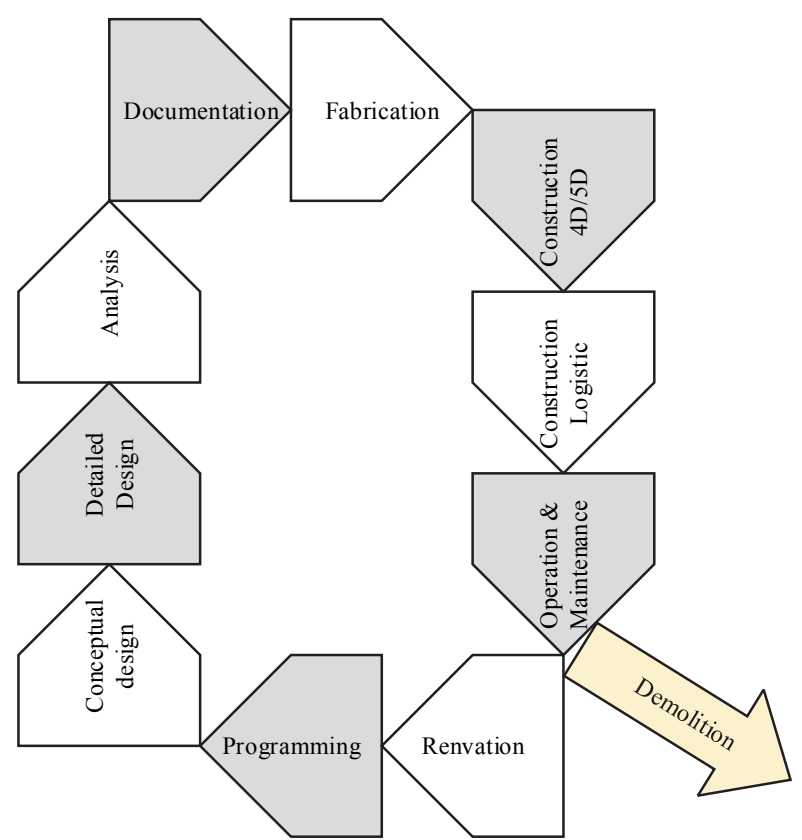

Fig. 1. BIM Capacities and Functions

\subsection{A Review of the Previous Studies [conducted] on PMBOK \& BIM Fields}

Bryde et al. (2013) discuss the benefits resulting from using BIM in projects. The paper analyzes the degree to which BIM is used in construction projects. The data of 35 construction projects which employed BIM are examined and reviewed in this paper. According to the reports of these projects using BIM results in benefits such as, saving time, reducing costs, and controlling through the project lifecycle. Azhar (2011) examined the benefits, risks, and challenges of BIM. The paper talks about the benefits, the probable risks, and the future challenges of the construction Industry. Initially the BIM concept is introduced with its benefits and applications (computer programs) in the construction industry. Then, based on three recent polls, the role of BIM in the construction industry and universities is discussed. Afterwards the case study of Hilton Aquarium in Atlanta is exemplified in quantities, demonstrating reductions in costs and time by making a Building Information Modeling. The information is related to 10 construction projects for the purpose of determining savings and investment returns in BIM. Finally, the risks and future challenges of BIM for the construction industry are examined. Fazli et al. (2014) assessed the effectiveness of BIM in project management. For a long time, the construction industry in Iran has been criticized for its lack of efficiency; it has been claimed that 80 percent of the data in the process of construction is similar for all of the projects; therefore, there are vast opportunities for improvement, and the presence of a project management is essential for the successful delivery of construction projects. The purpose of examining them (the construction projects in Iran) is, analyzing the ways how BIM can be used as an efficient tool by project managers to simulate the project situation in order to avoid reworking and waste of time and money. The conclusion was that, generally, project managers have little awareness of BIM, resulting in problems in understanding their plans. The study demonstrated that BIM can contribute to successful management of the projects. Compared to the traditional projects, BIM is presented as a more reliable basis for decision making. In his 2015 paper, some researchers, analyzed the challenges, consequences, and requirements of BIM in project management. The goal of the study was to demonstrate the relation between BIM and the role of project managers in construction projects; the study emphasizes the significance of having the adequate BIM knowledge and experience for the project management in order to achieve success. The paper also focuses on the necessity of, project managers having BIM knowledge and enrichment of 
A. Rezahoseini et al. / Journal of Project Management 4 (2019)

their experience. Bodaghee and Mahaamy (2014) focus on utilizing BIM in project management fields of knowledge, in a 2017 paper. The paper evaluates the advantages of using BIM, and its role in project management fields of knowledge (based on PMBOK standard). Moreover, it mentions the advantages of using BIM for project managers. Jupp (2017), focuses on environmental planning and management in 4D Building Information Modeling. His paper discusses the way for environmental planning and management by using the 4D potentials. The 4D modeling technologies and analysis besides structured work cycle, are presented as a basis for shaping an efficient environmental management and planning framework. The study introduces five technical prerequisites for an environment friendly construction planning. The five prerequisites are: planning and simulation, modeling environmental equipment, construction site modeling, modeling and envisioning the environmental significance, and the ability to comply with regulations. The paper also identifies the prerequisites for developing cooperation and supervision of environmental management systems before selecting the direction, for the further studies.

Murguia et al. (2017), while analyzing process combination framework for planning stage of residential buildings; debate that during the design process, BIM contributes to the enhancement of communication and vision, and also that it opens ways for continuation of improvement. The goal of the study is coordinating BIM, PMBOK (including communications and management of stakeholders), and LPDS, also development of a process combination framework for enhancing vision and communication during the design stage. In addition, the study is applied on case study of designing a residential building in Lima (Murguia et al., 2017). According to past studies, research on the impacts of BIM capabilities on each of the areas of knowledge management in a project has not been conducted. Therefore, in this research, we try to determine the effect of each BIM capabilities on each of the Knowledge areas of project management and examine the impact of each of the project management knowledge areas on BIM capabilities through SAW analysis and rank the knowledge management areas of the project in terms of impact, and in Finally, we present the BIM process model can have great impact alongside with the project knowledge areas of management on implementations of the project.

\section{Presentation of the proposed process model for implementation of BIM in order to influence on knowledge areas owing to the fact that it has great frame work for project management as a standard}

A standard for each aspect of the project, such as range, time, cost, and quality (as the main objectives), to the management of resources, logistics, risk, communications and stakeholders (as knowledge of achieving these goals), has certain purposes and ultimately integrates them seamlessly; however, achieving these goals and processes in the form of project management (not at the management level, but at the level of engineering and implementation) requires a tool that is in line with the goals And the foregoing frameworks can make planning and processes in different areas of knowledge; we need to use tool and methodology in order to make optimal use of resources, to better manage risks, to establish relationships in a secure way between stakeholders, and to control project procurements; as a result, eventually to have a project with predetermined quality in the related scope. To find this tool and methodology we look at building information modeling, a concept that is rapidly expanding and is being implemented in advanced countries as a requirement. The BIM has proven that the more time spent on designing and constructing the model and attaching information to the information model, the more value it adds to the project and its stakeholders, and with a great deal of potential in the various phases of the project that it presents. It improves almost all aspects of the project. That is why its use has become so popular all over the world, and in some countries the BIM multi-dimensional model is a requisition for obtaining construction permission. In the following research, we try to identify the effects of BIM capabilities on the PMBOK knowledge areas and, by interviewing experts and questionnaires, we have will discuss the opinion of the experts on these two domains in relation to their mutual effects on each other. First, we introduce the various BIM capabilities described in the previous section, and select some of them that are most important for the majority of experts, and then examine their 
impact in each of the PMBOK knowledge domains. In the following, according to the collected opinions, we tried to summarize the sets of experts' views in Table 3. Then, through the questionnaires, the effectiveness of each of the areas of project management knowledge on the capabilities BIM will be measured, and we obtain and rank them through SAW analysis. Finally, in Figure 3, we introduce a proposed model for implementing BIM to influence the knowledge areas of project management.

\section{Table 3}

The effect of the capabilities of BIM on project management fields of knowledge

\begin{tabular}{|c|c|c|c|}
\hline \multirow{2}{*}{ Row } & \multirow{2}{*}{$\begin{array}{c}\text { capabilities of building's information } \\
\text { modeling }\end{array}$} & \multicolumn{2}{|c|}{ Project management fields of knowledge } \\
\hline & & Integration management & $\begin{array}{l}\text { Scope management } \\
\end{array}$ \\
\hline 1 & $\begin{array}{l}\text { Creating a 3D model of project and modify- } \\
\text { ing the model, plans and schedules automat- } \\
\text { ically in case of changes in project design } \\
\text { and execution } \\
\text { (Parametric capability of the 3D model) }\end{array}$ & $\begin{array}{l}\text { - Integrated recording of project information } \\
\text { on a 3D information model } \\
\text { - Making integrated changes in 3D infor- } \\
\text { mation model automatically; drawing (cut, } \\
\text { view), total costs of the project, the amount } \\
\text { of materials and time in case of any } \\
\text { changes in design } \\
\text { - Warnings from the system in case of any } \\
\text { mistake in design and conflict between } \\
\text { various disciplines (architecture, facilities, } \\
\text { power, mechanics) on 3D information } \\
\text { model }\end{array}$ & $\begin{array}{l}\text { - Visual display of design, 3D model and } \\
\text { clarifying the scope of the project to the } \\
\text { stakeholders since the information model } \\
\text { is highly detailed } \\
\text { - Modifying the scope of the product auto- } \\
\text { matically in case of any changes in design } \\
\text { or using the parametric capability }\end{array}$ \\
\hline 2 & $\begin{array}{l}\text { High accuracy in estimation of costs and } \\
\text { project required tools and value engineering, } \\
\text { all in a short period of time } \\
\text { (Accurate quantity surveying and estimat- } \\
\text { ing) }\end{array}$ & $\begin{array}{l}\text { - Integrated recording of materials infor- } \\
\text { mation on a 3D information model and de- } \\
\text { termining the accurate amount of materials } \\
\text { since the information model is highly de- } \\
\text { tailed and automatic modification of mate- } \\
\text { rials in case of any changes in design } \\
\text { - Integrated recording of the total costs of } \\
\text { materials on a 3D information model and } \\
\text { determining the accurate costs of materials }\end{array}$ & $\begin{array}{l}\text { - A completely specified scope - accurate } \\
\text { estimation of materials and their costs } \\
\text { - Automatic update of costs and amount of } \\
\text { materials in case of any changes in design } \\
\text { and scope of the project } \\
\text { - The capability of value engineering of var- } \\
\text { ious design alternatives in any phase of de- } \\
\text { sign based on different scopes }\end{array}$ \\
\hline
\end{tabular}

3 Resolving the errors and conflicts in various disciplines design before construction phase and so avoiding reworks and waste of time and costs

(Clash detection)

4 Creating a comprehensive and common online data base for the stakeholders in order to have an easy access to the information and Decrease commute documents, engineering documents and drawing (Archiving)

5 Development of collaboration and optima design of the project using all key stakeholders in the process of design and using their opinions before the execution phase (Integrated design and development of collaboration)

6 Accurate analyzing of light and energy and stable design in order to reducing the use of energy

(Sustainable design) determining the accurate costs of materials since the information model is highly detailed and automatic modification of the project costs in case of any changes in design

- Detecting conflicts, errors and contrasts between various disciplines (architecture, facilities, power, mechanics) due to the integrated design of the information model and resolving these conflicts before project construction phase

- Integrated attachment of the information of the project (guaranties, warranties, catalogs, costs of materials, the quantity and type of materials, graduates, etc.) from the planning phase to the operation phase

- having the 3D information model in a cloud environment and online using of the information of the project by the key stakeholders on a 3D information model and using this information in future projects

- using different opinions and viewpoint of all key stakeholders (client, contractor, designer and beneficiary) in the process of design and planning of the project since the information model is $3 \mathrm{D}$ and due to their appropriate view on project

- attaching project information by every stakeholder in a cloud environment on a 3Dinformation model and reducing the information traffic and reworks by stakeholders and increasing the collaboration between them

- exchanging opinions between various professional teams involved in the project in an integrated cloud environment

- Integrated modification of the 3D information model based on the integrated analysis of light, energy, brightness, energy of the wind and the effects of the stable designing on costs and time of the project
- Reducing reworks and their effects (costs, time, quality and etc.) by presenting a completely specified and explicit scope with no conflict, error and contrast before construction phase

- High details and Integrated design - accurate and explicit scope

- A correct perception and an appropriate vision of project through an accurate and explicit scope; so every stakeholder's duty in execution of the project will be more precise and the stakeholders will be providing with the information of different phases of the project

- reducing the probability of changing the scope and its effect on project lifecycle due to the collaboration of all key stakeholders in the process of design and applying their opinions in 3D information model and finally determining an explicit and confirmed scope

- changing scope in consideration of energy, light and providing a stable and optimal project scope regarding energy 


\begin{tabular}{|c|c|}
\hline Row & $\begin{array}{c}\text { capabilities of building's information } \\
\text { modeling }\end{array}$ \\
\hline 7 & $\begin{array}{l}\text { Presenting a full package of both project and } \\
\text { model information such as construction and } \\
\text { utilizing all this information in order to } \\
\text { make the operation management simple and } \\
\text { smart } \\
\text { (Operation \maintenance and repair man- } \\
\text { agement) }\end{array}$ \\
\hline
\end{tabular}

8 Accurate estimate of required activities for project and facilitate the work breakdown structure in $3 \mathrm{D}$ form and the process of project construction

(Simulating the construction process)

9 Increase in fabricating and expanding industrialization on complicated designs (fabricating capability)

10 Creating a 3D model of project and modifying the model, plans and schedules automatically in case of changes in project design and execution

(Parametric capability of the 3D model)

11 High accuracy in estimation of costs and project required tools and value engineering, all in a short period of time

(Accurate quantity surveying and estimating)

12 Resolving the errors and conflicts in various disciplines design before construction phase and so avoiding reworks and waste of time and costs

(Clash detection)

13 Creating a comprehensive and common online data base for the stakeholders in order to have an easy access to the information and Decrease commute documents, engineering documents and drawing

(Archiving)

14 Development of collaboration and optimal design of the project using all key stakeholders in the process of design and using their opinions before the execution phase (Integrated design and development of collaboration)
Integration management

- Effective maintenance and repair planning due to the integration of the 3D information model and its details and accurate information on the model

- Reducing difficulties of the phase of operation due to the integrated design and increasing the collaboration between colleagues and using the views of beneficiary on model $3 \mathrm{D}$ design

- A better view on construction method by simulating the construction process and a better perception of the work breakdown structure by Navisworks software due to the integrated design of the information model and its details and the capability of detecting conflicts

- Automatic update of the schedule in case of any changes in the design

- Increase in accuracy of prefabricating since the 3D information model is highly detailed by any discipline and applying these decisions on the model and observing the changes in costs and time and other part of the project all in an integrated way

- Having updated as-built maps in every stage of the project due to the parametric capability of the project and reducing the time required in order to prepare as-built maps

- An appropriate and perfect view on project scope by key stakeholders and decrease in changes and claims during the project execution and their following effects on time

- The ability of value engineering of different alternatives in every stage of design and reducing the time of the value engineering process

- Reducing the time required by inaccurate traditional quantity surveying and estimating through automatic software computation

- More precise time scheduling of project necessary activities by accurate quantity surveying and estimating and therefore computation of required workloads for project execution

- Resolving conflicts, contrasts and errors in the design within the shortest period of time and reducing the documents traffic between stakeholders

- Reducing reworks caused by conflicts between various disciplines and so their effects on time

- Having an online information base used by every stakeholder based on their authority level in each stage

- Reducing the time wasted on documents traffic in the traditional form and recording information in a single $3 \mathrm{D}$ model

- The ability of team working in an integrated virtual environment (cloud) so there would be no need for their presence in a specific site

- Reducing team physical sessions in a specific site
Scope management

Creating a 3D information model such as construction and an explicit and accurate scope corresponding to the finished project and recording all the required information in order to use in the operation phase (guarantees, seller's information, costs, catalogs and etc.)

- A completely specified and explicit scope since the $3 \mathrm{D}$ information model is highly detailed and does not change over the time - accurate estimation of project completion time and a better perception of work breakdown structure and facility in required workloads

- Assisting in prefabricating since the 3D information model is highly detailed and an explicit and specified scope

- An appropriate and perfect view on project by every stakeholder involved in the project before the construction phase and reducing reworks caused by inappropriate view and claims that may be followed and their costs and effects

- Accurate quantity surveying and estimating and computing costs of the project execution since the $3 \mathrm{D}$ information model is highly detailed

- Computing quantities and costs caused by them and its automatic modification in case of any changes in design

- Reducing the costs caused by reworks through detecting conflicts and errors in design and contrasts between various disciplines before the construction phase

- Utilizing financial information of project and the lessons learned in order to manage the costs of future projects due to the great potency of documentation of $3 \mathrm{D}$ information model

- Reducing the effects of reworks on costs due to the participation of all key stakeholders in design of the project and decreasing the claims that follow before the construction stage 


\begin{tabular}{|c|c|}
\hline Row & $\begin{array}{c}\text { capabilities of building's information } \\
\text { modeling }\end{array}$ \\
\hline 15 & $\begin{array}{l}\text { Accurate analyzing of light and energy and } \\
\text { stable design in order to reducing the use of } \\
\text { energy } \\
\text { (Sustainable design) }\end{array}$ \\
\hline 16 & $\begin{array}{l}\text { Presenting a full package of both project and } \\
\text { model information such as construction and } \\
\text { utilizing all this information in order to } \\
\text { make the operation management simple and } \\
\text { smart } \\
\text { (Operation } \backslash \text { maintenance and repair man- } \\
\text { agement) }\end{array}$ \\
\hline 17 & $\begin{array}{l}\text { Accurate estimate of required activities for } \\
\text { project and facilitate the work breakdown } \\
\text { structure in } 3 \mathrm{D} \text { form and the process of pro- } \\
\text { ject construction } \\
\text { (Simulating the construction process) }\end{array}$ \\
\hline 18 & $\begin{array}{l}\text { Increase in fabricating and expanding indus- } \\
\text { trialization on complicated designs } \\
\text { (Fabricating capability) }\end{array}$ \\
\hline 19 & $\begin{array}{l}\text { Creating a 3D model of project and modify- } \\
\text { ing the model, plans and schedules automat- } \\
\text { ically in case of changes in project design } \\
\text { and execution } \\
\text { (Parametric capability of the 3D model) }\end{array}$ \\
\hline 20 & $\begin{array}{l}\text { High accuracy in estimation of costs and } \\
\text { project required tools and value engineering, } \\
\text { all in a short period of time } \\
\text { (Accurate quantity surveying and estimat- } \\
\text { ing) }\end{array}$ \\
\hline
\end{tabular}

21 Resolving the errors and conflicts in various disciplines design before construction phase and so avoiding reworks and waste of time and costs

(Clash detection)

22 Creating a comprehensive and common online data base for the stakeholders in order to have an easy access to the information and Decrease commute documents, engineering documents and drawing

(Archiving)

23 Development of collaboration and optimal design of the project using all key stakeholders in the process of design and using their opinions before the execution phase (Integrated design and development of collaboration)

24 Accurate analyzing of light and energy and stable design in order to reducing the use of energy

(Sustainable design)
- Speeding up project operation and reducing difficulties and reworks followed by project closure and operation due to the project integrated design by every stakeholder involved

- The ability of simulating the construction process and detecting possible problems or opportunities of improving the time schedule

- Reducing the project cycle time by prefabricating and outsourcing since the $3 \mathrm{D}$ information model is highly detailed

- Improving project quality through appropriate and perfect views of key stakeholders and applying their opinions in 3D information model before the construction stage and reducing reworks and their following impacts on project quality

- Presenting precise workshop drawing with high quality

\section{Scope management}

- increasing costs due to the analysis of energy and light in the design stage but a total decrease in costs concerned with energy consumption in project lifecycle and operation stage, considering the fact that the effects of reducing costs in operation stage cannot be compared to the costs of analysis

- Reducing costs of maintenance and repair due to the full information recording of the project (guarantees, warrantees, seller's information, catalogs, equipment instructions and etc.) and presenting a precise time schedule for maintenance and repair on the 3D model

- Reducing the costs caused by selecting inappropriate construction method through the construction process and the project logistics

- Reducing the costs through prefabricating considering the difficulties of working in site in some specific projects

- Reducing risks caused by reworks and claims through appropriate and perfect views of key stakeholders and representing a $3 \mathrm{D}$ information model

- Reducing risks caused by uncertainty in cost and quantity of materials required by project through accurate and automatic quantity surveying and estimating

- Reducing risks caused by claims between contractor and employer over project costs

- Improving project quality by Conflict detection, resolving errors and contrasts of the design before the project execution phase and reducing reworks and their following impacts on quality

- Reducing risks caused by reworks and their effects including: increase of time, increase of cost, decrease of quality and etc. through conflict detection, detecting errors in design and contrasts between various disciplines before the execution phase

- Reducing risks caused by documents and plans getting lost through documentation on a 3D information model instead of using thousands of paper sheets

- Improving project quality by reducing claims and the following reworks due to the integrated design by key stakeholders and cooperation between them from primary stages on a 3D information model
- Reducing risks (related to cost, time and reworks) caused by inappropriate view and perception of stakeholders and their claims by using their opinion in 3D information model and reaching an agreement before the construction phase

- Reducing risks caused by lack of constructability before the construction phase by using contractor and project executive manager's point of views in design

- Reducing cost-related risks, increase in energy prices during the project operation time by accurate design and analysis of energy and light in the design phase 


\begin{tabular}{|c|c|}
\hline Row & $\begin{array}{c}\text { capabilities of building's information } \\
\text { modeling }\end{array}$ \\
\hline 25 & $\begin{array}{l}\text { Presenting a full package of both project and } \\
\text { model information such as construction and } \\
\text { utilizing all this information in order to } \\
\text { make the operation management simple and } \\
\text { smart } \\
\text { (Operation \maintenance and repair man- } \\
\text { agement) }\end{array}$ \\
\hline 26 & $\begin{array}{l}\text { Accurate estimate of required activities for } \\
\text { project and facilitate the work breakdown } \\
\text { structure in 3D form and the process of pro- } \\
\text { ject construction } \\
\text { (Simulating the construction process) }\end{array}$ \\
\hline 27 & $\begin{array}{l}\text { Increase in fabricating and expanding indus- } \\
\text { trialization on complicated designs } \\
\text { (fabricating capability) }\end{array}$ \\
\hline 28 & $\begin{array}{l}\text { Creating a 3D model of project and modify- } \\
\text { ing the model, plans and schedules automat- } \\
\text { ically in case of changes in project design } \\
\text { and execution } \\
\text { (Parametric capability of the 3D model) }\end{array}$ \\
\hline
\end{tabular}

29 High accuracy in estimation of costs and project required tools and value engineering, all in a short period of time (Accurate quantity surveying and estimating)

30 Resolving the errors and conflicts in various disciplines design before construction phase and so avoiding reworks and waste of time and costs

(Clash detection)

31 Creating a comprehensive and common online data base for the stakeholders in order to have an easy access to the information and Decrease commute documents, engineering documents and drawing

(Archiving)

32 Development of collaboration and optimal design of the project using all key stakeholders in the process of design and using their opinions before the execution phase

(Integrated design and development of collaboration)

33 Accurate analyzing of light and energy and stable design in order to reducing the use of energy (Sustainable design)

34 Presenting a full package of both project and model information such as construction and utilizing all this information in order to make the operation management simple and smart

(Operation $\backslash$ maintenance and repair management)
- Improving execution quality by simulating appropriate method for execution

- Increase in the quality of building components through more focused prefabricating by manufacturers and decrease in risks and difficulties related to fabricating these components in the site of the project

- A lot of human resources are used in order to modify plans which BIM aims to avoid the construction process and selecting an

Scope management

- Reducing risks followed by problems and difficulties during the operation time, or late project operation through applying operator's point of view from the primary stages to the closure stage

- Reducing risks caused by incorrect and inaccurate planning (such as costs related to maintenance and repair of materials, project logistics plan) by simulating the construction process

- Reducing risks caused by inadaptability of project components in the site of project through accurate and high quality prefabricating of components in factories

- 3D displays of the project logistics (exact time of materials arrival to the site, and equipment and labors' working schedule) and an appropriate view on execution and project logistics before the execution phase

- Visual display of design and making sure that every stakeholder understands the design and the existing situation

- Automatic update of the quantity of materials in case of any changes in design

- Determining the precise quantity of required materials, along with the following costs automatically

- Saving resources and their related costs automatically through value engineering

- Decrease in wasting of resources due to the reworks caused by conflicts between various disciplines during execution by detecting conflicts, errors and contrasts in design before the construction phase

- Accurate and comprehensive documentation of utilized resources and their following costs along with a full package of information (including: seller's information, cost, guarantees, catalogs etc.) and applying this information in future projects

- Reducing reworks and their effects on resources (resources which are lost due to the reworks, human resources in order to do the tasks over again) by applying stakeholders' point of views in design before the execution phase

- Team members collaboration in a virtual integrated environment (cloud) so that there would be no need to their physical presence in one specific site Accurate and automatic quantity surveying and estimating before the construction phase and facilitating the process of bidding

- Reducing claims between contractor and employer in the execution phase due to the costs, for accurate estimating of cost and materials before the execution phase

- Reducing problems and claims between contractor and plan consultant in the execution phase through detecting conflicts, errors and contrasts in the design before the execution of project

- Recording all of the information related to contract, guarantees, warranties, catalogs and invoice on a 3D information model and reducing the possible claims between project factors

- Reducing claims between project factors and the following effects (such as: increase in cost of the project, increase in time, lost benefit) through their integrated collaboration in the early stages of the project on a $3 \mathrm{D}$ information model and reaching an agreement before the execution phase
- Increasing the lifetime of the resources utilized in project through accurate maintenance and repair planning
- Recording every information related to the project (including: guarantees, warranties, guidelines for maintenance and repair of the components, safety tips such as fire containment) on the 3D information model and utilizing this information in the project operation phase 


\begin{tabular}{|c|c|c|c|}
\hline \multirow{2}{*}{ Row } & \multirow{2}{*}{$\begin{array}{c}\text { capabilities of building's information } \\
\text { modeling }\end{array}$} & \multicolumn{2}{|c|}{$\begin{array}{l}\text { Project management fields of knowledge } \\
\end{array}$} \\
\hline & & Integration management & Scope management \\
\hline 35 & $\begin{array}{l}\text { Accurate estimate of required activities for } \\
\text { project and facilitate the work breakdown } \\
\text { structure in 3D form and the process of pro- } \\
\text { ject construction } \\
\text { (Simulating the construction process) }\end{array}$ & $\begin{array}{l}\text { - Accurate estimating of the required work } \\
\text { resources through simulating the construc- } \\
\text { tion process and project logistics }\end{array}$ & $\begin{array}{l}\text { - Synchronization between ordering mate- } \\
\text { rials, fabrication of components and de- } \\
\text { livery schedule for every component } \\
\text { based on simulating the construction pro- } \\
\text { cess and project logistics } \\
\text { - Improvement in managing suppliers } \\
\text { through simulating the project logistics } \\
\text { (such as: order time, order size, duration } \\
\text { of retaining materials, paid expenses etc.) }\end{array}$ \\
\hline 36 & $\begin{array}{l}\text { Increase in fabricating and expanding indus- } \\
\text { trialization on complicated designs } \\
\text { (fabricating capability) }\end{array}$ & $\begin{array}{l}\text { - Optimal balance by cost of components pre- } \\
\text { fabricating in factories comparing to the } \\
\text { work resources required in order to fabri- } \\
\text { cate project elements in site of the project } \\
\text { and its following costs }\end{array}$ & $\begin{array}{l}\text { - Increase in precision, quality and speed } \\
\text { of fabricating project required elements } \\
\text { through prefabricating by suppliers (who } \\
\text { no longer considered suppliers but as } \\
\text { subcontractors) since the 3D model is } \\
\text { highly detailed }\end{array}$ \\
\hline 37 & $\begin{array}{l}\text { Creating a 3D model of project and modify- } \\
\text { ing the model, plans and schedules automat- } \\
\text { ically in case of changes in project design } \\
\text { and execution } \\
\text { (Parametric capability of the 3D model) }\end{array}$ & $\begin{array}{l}\text { - Visual, detailed display of design and mak- } \\
\text { ing sure that every stakeholder understands } \\
\text { the design and the existing situation }\end{array}$ & $\begin{array}{l}\text { - Explicit and appropriate views of the key } \\
\text { stakeholders on project and reaching an } \\
\text { agreement before the execution phase }\end{array}$ \\
\hline 38 & $\begin{array}{l}\text { High accuracy in estimation of costs and } \\
\text { project required tools and value engineering, } \\
\text { all in a short period of time } \\
\text { (Accurate quantity surveying and estimat- } \\
\text { ing) }\end{array}$ & $\begin{array}{l}\text { - Creating clear connections and displaying } \\
\text { accurate information of required resources } \\
\text { and their costs }\end{array}$ & $\begin{array}{l}\text { - Reaching of an agreement based on pro- } \\
\text { ject required materials and their follow- } \\
\text { ing costs } \\
\text { - Presenting various alternatives based on } \\
\text { value engineering so it is possible for the } \\
\text { stakeholders to decide based on project } \\
\text { cost and material }\end{array}$ \\
\hline 39 & $\begin{array}{l}\text { Resolving the errors and conflicts in various } \\
\text { disciplines design before construction phase } \\
\text { and so avoiding reworks and waste of time } \\
\text { and costs (Clash detection) }\end{array}$ & & $\begin{array}{l}\text { - Avoiding hostile relationships and quar- } \\
\text { rels between stakeholders due to the op- } \\
\text { posite interests by conflict detection, } \\
\text { clarifying, detecting errors and problems } \\
\text { before the execution stage }\end{array}$ \\
\hline 40 & $\begin{array}{l}\text { Creating a comprehensive and common } \\
\text { online data base for the stakeholders in order } \\
\text { to have an easy access to the information and } \\
\text { Decrease commute documents, engineering } \\
\text { documents and drawing (Archiving) }\end{array}$ & $\begin{array}{l}\text { - Having an up-to-date and precise infor- } \\
\text { mation base of project information (includ- } \\
\text { ing updated and accurate drawing, time } \\
\text { schedule, quantities, cost and quantity } \\
\text { schedules) }\end{array}$ & $\begin{array}{l}\text { - Monitoring every activities done for all } \\
\text { key stakeholders in a cloud environment } \\
\text { and inform them of work progress and us- } \\
\text { ing their point of views in every moment } \\
\text { and recording this information in a 3D in- } \\
\text { formation model }\end{array}$ \\
\hline 41 & $\begin{array}{l}\text { Development of collaboration and optimal } \\
\text { design of the project using all key stakehold- } \\
\text { ers in the process of design and using their } \\
\text { opinions before the execution phase } \\
\text { (Integrated design and development of col- } \\
\text { laboration) }\end{array}$ & $\begin{array}{l}\text { - Increasing coordination and effective rela- } \\
\text { tionships considering every member's au- } \\
\text { thority level on a 3D information model } \\
\text { - The ability of exchanging and adapting } \\
\text { models of other professional groups in- } \\
\text { volved in the project (structure model, facil- } \\
\text { ity model and architecture model) in an in- } \\
\text { tegrated environment and improving rela- } \\
\text { tionships between different professional } \\
\text { groups }\end{array}$ & $\begin{array}{l}\text { - Considering stakeholders' requirements } \\
\text { and their agreements on a 3D model be- } \\
\text { fore the execution phase through their } \\
\text { collaboration during special sessions and } \\
\text { receiving their point of views and apply- } \\
\text { ing them on the information model } \\
\text { - Receiving stakeholders' point of views in } \\
\text { every moment of the project lifecycle in } \\
\text { a cloud environment so that there would } \\
\text { be no need to their physical presence }\end{array}$ \\
\hline
\end{tabular}

42 Accurate analyzing of light and energy and stable design in order to reducing the use of energy (Sustainable design)

43 Presenting a full package of both project and model information such as construction and utilizing all this information in order to make the operation management simple and smart

(Operation \maintenance and repair management)

44 Accurate estimate of required activities for project and facilitate the work breakdown structure in $3 \mathrm{D}$ form and the process of project construction

(Simulating the construction process)

45 Increase in fabricating and expanding industrialization on complicated designs (fabricating capability)
- Optimal balance by cost of components pre-

Visual, detailed display of design and making sure that every stakeholder understands the design and the existing situation 
The SAW technique is one of the most used MADM techniques. It is simple and serves the basis of most MADM techniques such as AHP and PROMETHEE which benefits from additive property to calculate final scores of alternatives. In SAW technique, final score of each alternative is calculated as follows

$$
P_{i}=\sum_{j=1}^{K} W_{j} \times r_{i j}
$$

The steps taken to calculate the extent of the impact of knowledge management areas of the project on building information modeling capabilities:

1) First, through questionnaires of experts, the effectiveness of each of the project management knowledge areas (options) from the BIM capabilities (indicators) using the 3-parameter beta distribution and Likert scale (Effective) has been demonestrated.

\begin{tabular}{lll}
\hline \multicolumn{3}{c}{$\frac{a+4 b+c}{6}=$ average Weighted impact rate } \\
\hline The Lowest Effect $=\mathrm{a}$ & The Most Effective Level $=\mathrm{b}$ & Maximum Effect $=\mathrm{c}$ \\
\hline
\end{tabular}

2) From the questionnaires prepared by different experts, we make an average of the arithmetic to determine the decision-making matrix of the impact level of knowledge management areas of the project.

- Given that the type of all indicators (BIM capabilities) is the same and of a type of positive effect, so there is no need to be quantified and the weight of each of the indicators is calculated by adding The influence of each indicator into the elements of the decision making matrices.

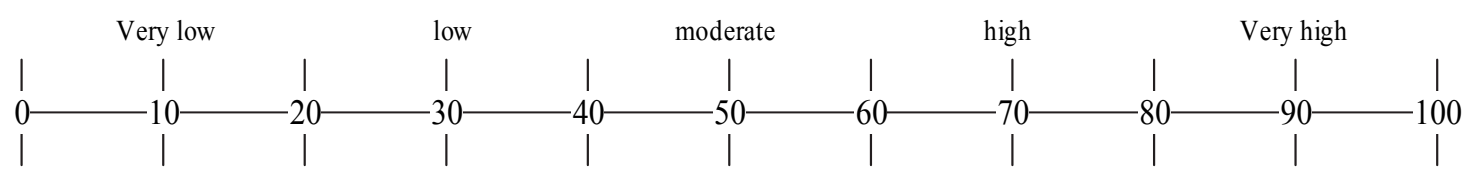

- The weight gain of indicators is determined by the multiplication of indicators weights in to the degree of impressibility of every one the project management knowledge areas.

In Table 4, the decision matrix resulting from the average of the arithmetic of the various questionnaires and the desirability (effectiveness) of each of the areas is shown.

Table 4

Matrix of decision making and calculation of the saw method

\begin{tabular}{|c|c|c|c|c|c|c|c|c|c|c|c|}
\hline \multirow[b]{2}{*}{ integrated } & \multirow[b]{2}{*}{74.3} & \multirow[b]{2}{*}{76.2} & \multicolumn{5}{|c|}{ Decision making Average } & \multicolumn{4}{|c|}{$\mathrm{Uj}$} \\
\hline & & & 76.5 & 77.3 & 71.8 & 30.1 & 64.6 & 78.5 & 66.7 & 71.5 & \multirow{11}{*}{4317.75} \\
\hline scope & 73.3 & 68.8 & 62.5 & 55.8 & 36.5 & 20.8 & 38.8 & 51.1 & 61.4 & 55.2 & \\
\hline time & 69.2 & 63.3 & 68.5 & 61.8 & 67.7 & 23.0 & 32.7 & 62.5 & 41.5 & 58.0 & \\
\hline cost & 39.5 & 63.9 & 65.4 & 55.1 & 36.4 & 37.8 & 29.9 & 38.4 & 52.3 & 48.2 & \\
\hline quality & 56.0 & 11.5 & 74.0 & 8.5 & 37.0 & 53.3 & 47.5 & 29.5 & 64.6 & 42.4 & \\
\hline risk & 52.3 & 59.3 & 60.0 & 46.4 & 52.1 & 11.3 & 35.3 & 35.7 & 47.6 & 47.8 & \\
\hline resource & 46.2 & 63.9 & 65.4 & 31.2 & 58.1 & 21.0 & 41.0 & 40.9 & 34.4 & 47.4 & \\
\hline procurement & 49.1 & 61.9 & 68.6 & 57.5 & 61.2 & 6.3 & 39.1 & 53.0 & 63.3 & 55.2 & \\
\hline communication & 35.3 & 39.9 & 50.0 & 51.2 & 70.2 & 3.8 & 20.5 & 39.8 & 32.9 & 41.7 & \\
\hline stakeholder & 54.4 & 38.5 & 42.3 & 49.8 & 58.1 & 5.0 & 19.7 & 39.4 & 29.4 & 40.7 & \\
\hline 4317.75 & 549 & 547 & 633 & 494 & 549 & 212 & 369 & 468 & 494 & sum & \\
\hline total sum & $13 \%$ & $13 \%$ & $15 \%$ & $11 \%$ & $13 \%$ & $5 \%$ & $9 \%$ & $11 \%$ & $11 \%$ & $\mathrm{Wj}$ & total sum \\
\hline
\end{tabular}


In Fig. 2, the impact diagrams of each of the project management knowledge areas are illustrated by the BIM capabilities using questionnaires.

As outlined in the diagram, BIM capabilities are influential in all areas of knowledge and have the greatest impact on integration management, which can also be expected according to the type of building information modeling system, as BIM seeks to Integration of all project information into a 3D information model and can be used as a suitable methodology along with different standards. Now, in Fig. 3 and Fig. 4, the BIM proposed process model for implementing knowledge management areas of the project is shown.

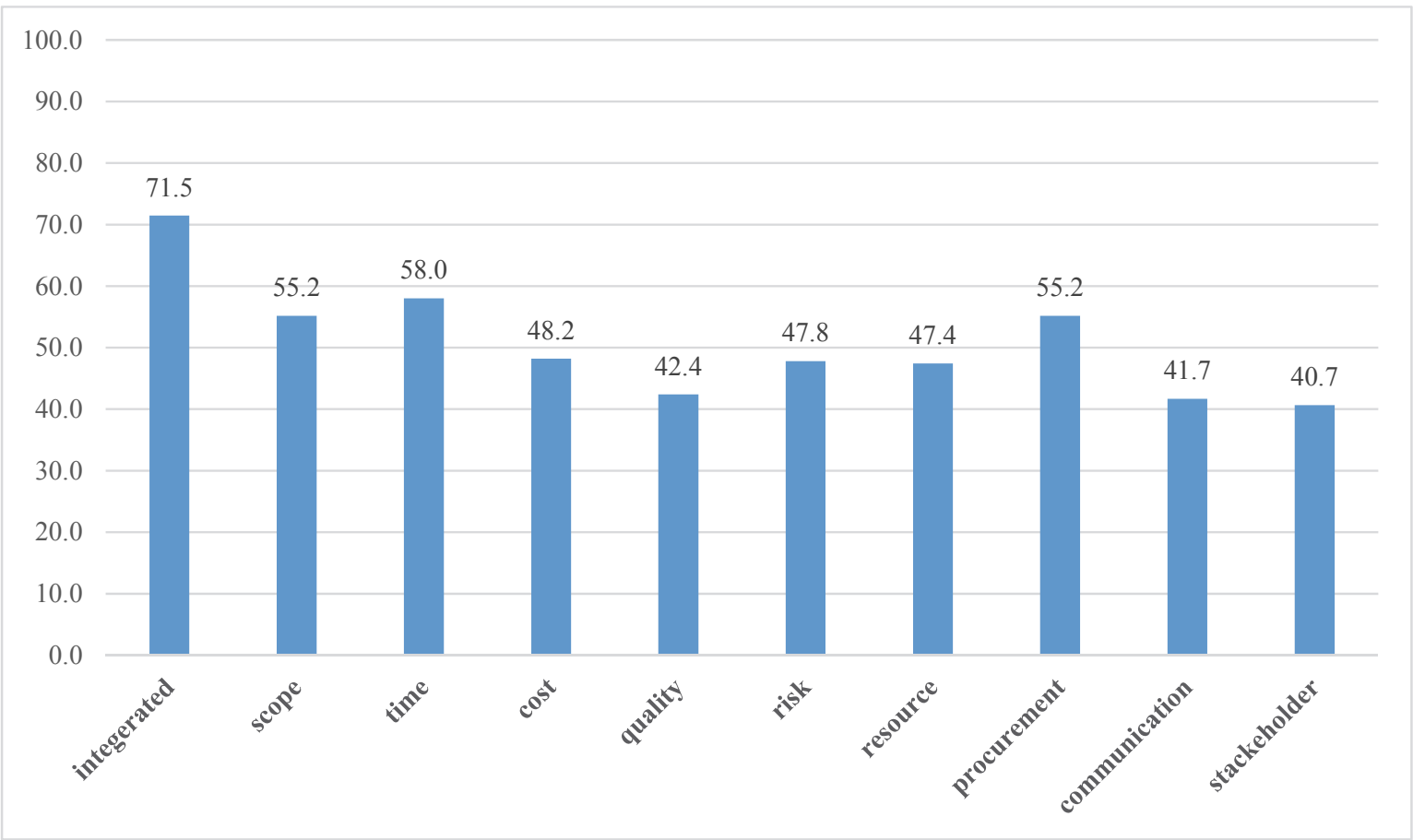

Fig. 2. Graph of the extent of the impact of knowledge areas on BIM capabilities 


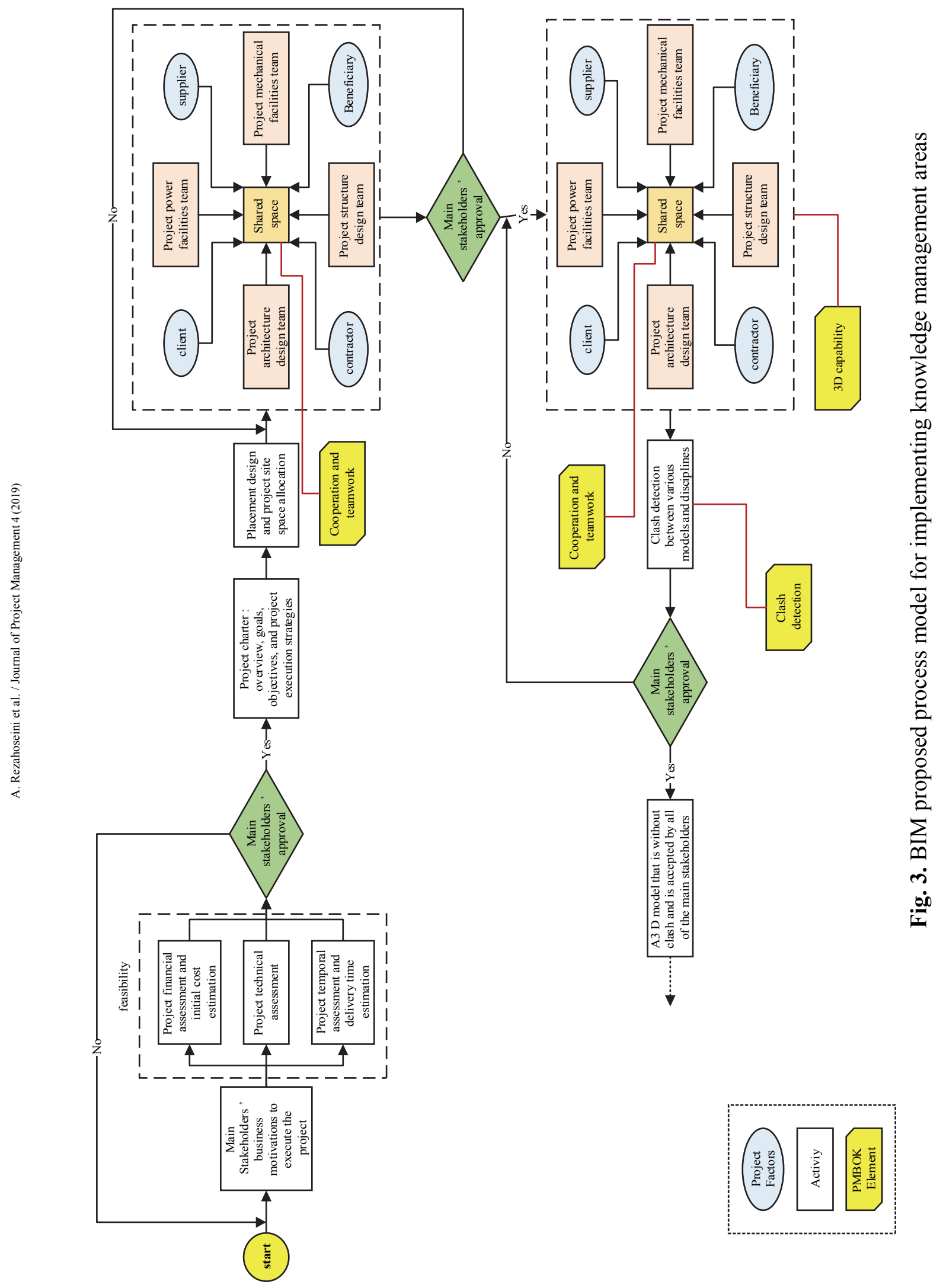




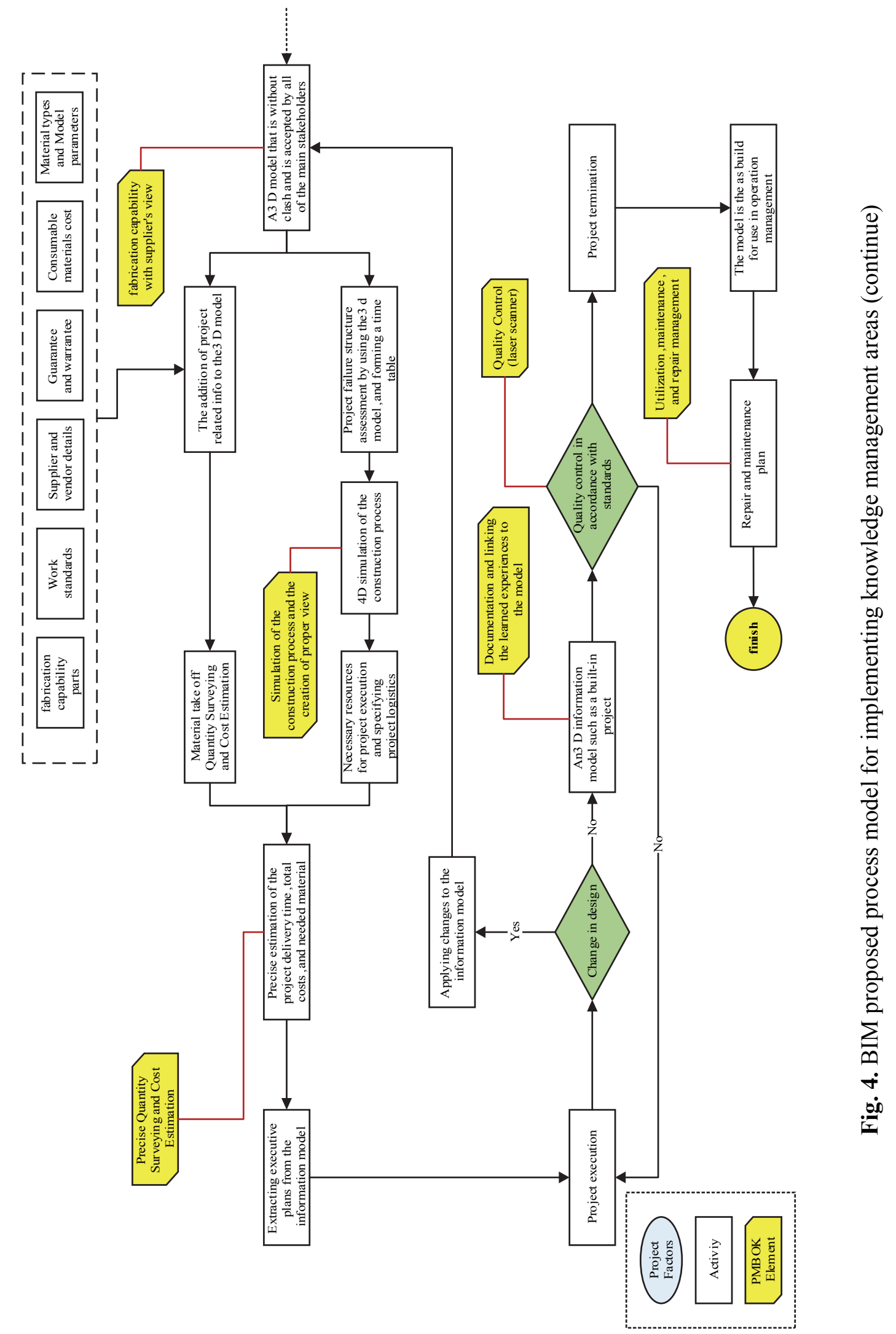




\section{Conclusion}

According to the collected questionnaires, we can summarize the impact of building information modeling capabilities in Table 5.

\section{Table 5}

Summary of the Effects of Building Information Modeling Capabilities on Project Management Knowledge Areas

\begin{tabular}{|c|c|}
\hline $\begin{array}{l}\text { Knowledge areas of project } \\
\text { management }\end{array}$ & Influence of Building Information Modeling \\
\hline Integration management & Integrated 3-D information model and its parametric functionality \\
\hline Limited management & Determine the precise scope of the project through the 3-D information model \\
\hline Time Management & Reduce project execution time by reducing duplication \\
\hline cost management & $\begin{array}{l}\text { Reduce costs through metering and accurate estimation and reduction of recy- } \\
\text { cling }\end{array}$ \\
\hline Quality management & $\begin{array}{l}\text { Improve the quality of the project by providing detailed project details and in- } \\
\text { teroperability }\end{array}$ \\
\hline risk management & Reducing negative risks through a proper vision of the project \\
\hline resource management & $\begin{array}{l}\text { Identify the logistics of the project and the resources required through simula- } \\
\text { tion }\end{array}$ \\
\hline supply Management & Determine the exact materials and machinery needed for the project \\
\hline $\begin{array}{l}\text { Communication manage- } \\
\text { ment }\end{array}$ & Increasing communication and teamwork based on IPD contracts \\
\hline Stakeholder management & Enhance collaboration among key stakeholders and manage them better \\
\hline
\end{tabular}

So, we see that the application of the concept of BIM in all areas of PMBOK can be very effective. In fact, in addition to a few cases, most of the major BIM applications identified have affected all areas of project management knowledge. Therefore, BIM application directly facilitates project management, and many construction management problems. BIM application and can be used as a methodology for PMBOK standard project management.

\section{References}

Alshawi, M., \& Ingirige, B. (2003). Web-enabled project management: an emerging paradigm in construction. Automation in construction, 12(4), 349-364.

Azhar, S. (2011). Building information modeling (BIM): Trends, benefits, risks, and challenges for the AEC industry. Leadership and management in engineering, 11(3), 241-252..

Bodaghee, S., \& Mahaamy, A. (2014). Application of Building Information Modeling in Knowledge Management Knowledge Areas. Second International Management and Accounting Conference.

Broquetas, M. (2010). Using BIM as a project management tool: how can BIM improve the delivery of complex construction projects?. Master degree dessertation, University of Applied Sciences, Stuttgart.

Bryde, D., Broquetas, M., \& Volm, J. M. (2013). The project benefits of building information modelling (BIM). International journal of project management, 31(7), 971-980.

Dang, D. T. P., \& Tarar, M. O. I. Z. (2012). Impact of 4D modeling on construction planning process. Chalmers University of Technology Göteborg, Sweden.

Eastman, C., Teicholz, P., Sacks, R., \& Liston, K. (2011). BIM handbook: A guide to building information modeling for owners, managers, designers, engineers and contractors. John Wiley \& Sons.

Elbeltagi, E., \& Dawood, M. (2011). Integrated visualized time control system for repetitive construction projects. Automation in Construction, 20(7), 940-953.

Fazli, A., Fathi, S., Enferadi, M. H., Fazli, M., \& Fathi, B. (2014). Appraising effectiveness of Building Information Management (BIM) in project management. Procedia Technology, 16, 1116-1125. 
Golabchi, A., Akula, M. V. R. K., \& Kamat, V. R. (2013). Leveraging BIM for automated fault detection in operational buildings. In ISARC. Proceedings of the International Symposium on Automation and Robotics in Construction (Vol. 30, p. 1). Vilnius Gediminas Technical University, Department of Construction Economics \& Property.

Hergunsel, M. F. (2011). Benefits of building information modeling for construction managers and BIM based scheduling.

Jupp, J. (2017). 4D BIM for environmental planning and management. Procedia engineering, 180, 190-201.

Khoshnava, S., Ahankoob, A., Preece, C., \& Rostami, R. (2012). Application of BIM in construction safety. In Management in Construction Research Association (MiCRA). Postgraduate Conference, University Teknologi Malaysia, Malaysia.

Krygiel, E., \& Nies, B. (2008). Green BIM: successful sustainable design with building information modeling. John Wiley \& Sons.

Larson, E. W., \& Gray, C. F. (2015). A Guide to the Project Management Body of Knowledge: $P M B O K$ (®) Guide. Project Management Institute.

Liu, Z. (2010). Feasibility Analysis of BIM Based Information System for Facility Management at WPI (Doctoral dissertation, Worcester Polytechnic Institute.).

Migilinskas, D., Popov, V., Juocevicius, V., \& Ustinovichius, L. (2013). The benefits, obstacles and problems of practical BIM implementation. Procedia Engineering, 57, 767-774.

Murguia, D., Brioso, X., Ruiz-Conejo, L., \& Fernandez, L. (2017). Process Integration Framework for the Design Phase of a Residential Building. Procedia Engineering, 196, 462-469.

Wong, K. D., \& Fan, Q. (2013). Building information modelling (BIM) for sustainable building design. Facilities, 31(3/4), 138-157.

Parvan, K. (2012). Estimating the impact of Building Information Modeling (BIM) utilization on building project performance (Doctoral dissertation).

Rooke, J., Seymour, D., \& Fellows, R. (2004). Planning for claims: an ethnography of industry culture. Construction management and economics, 22(6), 655-662.

Teicholz, P. M. (2013). Labor-productivity declines in the construction industry: causes and remedies (a second look). AECbytes Viewpoint.

Winberg, A., \& Dahlqvist, E. (2010). BIM-the Next Step in the Construction of Civil Structures.

Young, N. W., Jones, S. A., Bernstein, H. M., \& Gudgel, J. (2009). The business value of BIM-getting building information modeling to the bottom line. Bedford, MA: McGraw-Hill Construction, 51 .

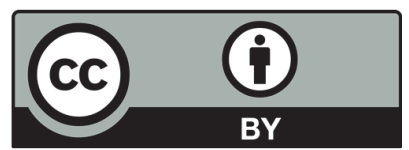

(C) 2018 by the authors; licensee Growing Science, Canada. This is an open access article distributed under the terms and conditions of the Creative Commons Attribution (CC-BY) license (http://creativecommons.org/licenses/by/4.0/). 